Original Research Paper

\title{
Chronological Age and Dental Age Using Demirjian in Down Syndrome Children
}

\author{
Azrra M. Nawawi, Meirina Gartika and Willyanti Soewondo \\ Department of Pediatric Dentistry, Faculty of Dentistry, Universitas Padjadjaran, Bandung, Indonesia
}

Article history

Received: 08-01-2018

Revised: 31-01-2018

Accepted: 6-03-2018

Corresponding Author: Willyanti Soewondo Department of Pediatric Dentistry, Faculty of Dentistry, Universitas Padjadjaran Bandung Indonesia

Email: willyanti.soewondo@fkg.unpad.a

\begin{abstract}
Down syndrome is a chromosomal abnormality (trisomy 21) characterized by an extra chromosome 21 . People with Down syndrome have impairement in mental and physical development, including delayed dental development. Dental age is stage of development of teeth measured by maturation stage of teeth. This study aims to determine or asses the growth or maturation of permanent teeth in children with Down syndrome. This research was a cross-sectional analysis. Analysis test using paired t-test to compare the average of chronological age to dental age, also unpaired t-test for comparing the dental age of children with Down syndrome to normal based on chronological age. The result showed that there was significant difference between chronological age and dental age in children with Down syndrome ( $p$-value $<0,05$ ). Thus, there was the difference of dental age between children with Down syndrome and normal but not significant ( $p$ value $>0,05$ ). The conclusion of this study showed that dental age more late than chronological age in children with Down syndrome. In spite dental age in Down syndrome children is descriptively later than in normal.
\end{abstract}

Keywords: Syndrome Down, Dental Age, Chronological Age, Demirjian

\section{Introduction}

Down Syndrome is a chromosomal disorder (Trisomy 21) in children and mostly revealed/found out in dental clinics. A person with Down Syndrome has an extra chromosome, namely chromosome 21. This extra chromosome will change the body genetical balance that might cause a change in physical characteristic and intellectual ability beside disorders of physiological function of the body. The incidence was 1 in 660 births with Trisomy 21 (Hidajat et al., 2005; Hurairah, 2012; Ghosh et al., 2010). The syndrome is a genetical anomaly caused by numeric aberation as a failure of replication process and nondisjunction of the cell (Hidajat et al., 2005; Rinaya, 2003; Moraes et al., 2007a). As results of chromosomal disorders, patients with Down Syndrome (DS) have disorders of mental and physical development including delayed dental development (Sjarif, 2011).

According to (As stated by) Moyers, dental growth and development were $78.5 \%$ genetically effected by genetical factors and $22 \%$ by environmental factors. Disorders of dental growth that caused by genetical factors begins at prenatal period, i.e., embryonic phase that is highly sensitive against disturbances and critical dental growth during prenatal period according to the phase of prenatal growth and development (Moyers, 2001).
Dental growth and development consists of dental development, calcification and eruption phases (McDonald and Avery, 2000). Chronological age is a right and easy parameter in estimating the growth and development globally, an accurate indicator of the developmental phase. Dental growth and development can be counted by dental age. Dental age is the right age in relevance with dental developmental phase, scored through dental maturation according to dental calcification and eruption. Based on dental calcification, the dental age is the main parameter in scoring the dental maturation, it is more accurate compared with chronological age (Stewart, 1982).

A study by Toscano (2007) found out that delayed growth of maxilla and mandibula occured in DS boys and girls. Other periodontal diseases (90-96\%) were caries, maloclusion (grade III), dental anomaly especially anodontia, delayed eruption of permanent tooth and macroglossia (11- 60\%). Santos (Moraes et al., 2007a) in a study on dental mineralizationon DS children using panoramic photos, found the delay in the development of caninus teeth and the second molar.

Sragriff-Curtin (Moraes et al., 2007b) stated the most common oral manifestation in DS patients were variable dental amount and morphology. The teeth eruption occurred 2-3 years later than in normal children and not in order. 
Tanner (1975) stated that dental age was estimated (ditentukan) in several ways based on the eruption, calcification grade and the association between dental forming and eruption. Radiographic image is one of the tools to find out the dental maturation in estimating the diagnosis and afterwards management (Tanner, 1975; Finn, 2005).

\section{Materials and Methods}

This was a cross sectional study. The subjects were children diagnosed as Down Syndrome who came to RSGM Universitas Padjadjaran during March-April 2016. Sample collection using purposive sampling. Analytical study using panoramic radiography to find out (to determine) the phase of dental calcification of left mandibular using Demirjian method. Statistical analysis using paired and unpaired t-test.

\section{Results}

The study subjects who fulfilled the inclusion criteria were 11 DS children and 11 normal children as control. Analysis were done on DS children to collect the dental age score to be compared with chronological age. The result is shown in Table 1.

There is difference between chronological and dental age in DS aged 6-14 years, descriptively. The rate in chronological age is 8.97 years and 7.91 years in dental age, that means dental age in DS children is delayed 1 year 1 month compared to chronological age.

The t-test was used to find out the difference between chronological age and dental age in children. Statistical analysis showed significant difference between chronological and dental age in DS children ( $p$ value $=$ $0.001)$. The rate of chronological age in DS children is higher compared to dental age (Table 1). Therefore, to find out the difference of dental age between DS and normal children based on chronological age, the t-test analysis was used. The result is shown in Table 2 .

Descriptively, dental age rate in DS children with 614 year chronological age is different with normal children. Dental age in DS children was 7-9 year and 9.2 year in normal children. Therefore, dental age in DS children at 6-14 year chronological age was 1 year 3 months later than in normal children. The t-test is used to find out the difference of dental age in DS and normal children. Analytical results showed the difference based on chronological age but not the result of the significant test $(p$-value $=0.1136)$.

\section{Discussion}

Each cell of the organisms has a genetical substance in the chromosome inside the nucleus. Each individual chromosome has a hereditary substance that will be passed down to its heredity. Generally an individual is said to have chromosomal variation or aberation when there is a genetical change, that might result in individual abnormality. This abnormality might result as characteristic symptoms, one of which is Down Syndrome (Suryo, 1986). A child with Down Syndrome has abnormality of Trisomy 21 chromosome that resulted as disorders of physical or mental development including delayed dental development (Sjarif, 2011).

The difference between chronological age and dental age in DS children aged 6-14 years, descriptively as well as statistically is shown in Table 1 , besides higher rate of chronological age than dental age in DS children that means delayed dental growth and development. Dental maturation indicates the biological maturation of a child growth. It highly correlated with dental age that might be detected since birth through adult phases. Dental age in children is estimated/counted/scored through dental calcification and eruption. The age, based on dental calcification and eruption is the most often used to predict the maturation, because dental age is more accurate based on dental growth and developmental phase (Grupta, 1996).

The Demirjian method is the most often used in estimating dental maturation because of its relatively high reliability, using only 8 phases of development and most detailed descriptive criteria according to the relative length of the crown and root of the tooth (Agurto et al., 2009; Maber et al., 2009). Other method in estimating dental maturation is Nolla method, which divides the calcification period of permanent teeth into 10 phases with a score for each phase, starting from the teeth forming up to the closing of apical foramen of the teeth. As seen on radiographic images, crypte forming (Phase 1) and so on until the closing of the tooth root apex (Phase 10). The permanent teeth of the upper and lower jaws ("rahang") were analysed and scored through panoramic radiography with only one site without molar 3 to get the total score of each phase. Nolla method used also conversion table (Apriyono, 2016). As stated in previous studies by Mussig et al. (2011) and Ondarza et al. (2011) there were delayed eruption of deciduous teeth in Down syndrome patients.

The result of this study is in accordance with SengriffCurtin (Moraes et al., 2007b) which stated the most common oral manifestation in DS patients were the variability of dental amount and morphology, 2-3 years delay of dental erruption that were not in order. Toscano (2007) found delayed growth of maxilla and mandibular and permanent teeth erruption in male and female DS children. Santor (Stewart, 1982) in his study on the chronology of dental mineralization in DS children panoramic images using Demirijan (2007), found a delay of development of caninus tooth and second molar; Moraes et al. (2007a) found different dental age and chronological age of less than 12 months. 
Table 1: The difference between chronological and dental age in Down syndrome using t-test

\begin{tabular}{lllllll}
\hline $\mathrm{N}$ & Rate of Chronologic age & Rate of dental age & Difference (month and year) & $\mathrm{SD}$ & $\mathrm{t}$ table & $\mathrm{p}$-value \\
\hline 11 & 8.97 & 7.91 & 1.14 & 0.912 & 4.13 & $\left.0.0010212^{*}\right)$ \\
\hline Note: ${ }^{*}$ ) Significant & & & & &
\end{tabular}

Table 2: Difference of dental age between DS and normal children based on chronologial age

\begin{tabular}{lllllll}
\hline $\mathrm{N}$ down syndrome & Rate & Dental age normal & SD down syndrome & Normal & t-count & $\mathrm{p}$-value \\
\hline 11 & 7.91 & 9.24 & 2.328 & 2.658 & -1.25 & $\left.0,1136^{*}\right)$ \\
\hline
\end{tabular}

Diz et al. (2011) stated that the difference between dental age and chronological age using Demirjian and Nolla methods were not significant, but using Demirjian method the comparison of dental age in boys and girls based on chronological age the result was significant and dental age in Down syndrome girls were later than in boys.

A normal standard in clinical value examination of child growth is needed so that physiological age could be compared with chronological age. Similarly chronological age children might show different biological developments (Smith, 1991).

Growth and development phase of a child is usually used as a standard in men's life. Development phase is related to the increase of structural maturation and complete organ functions. The cell and organ functions have also changes every time. Growth and development of a child is characteristically increased or decreased according to the structural differentiation of the body along growth age (Cohen, 1982).

\section{Conclusion}

Based on the study on Down Syndrome and normal children, it was concluded that in Down Syndrome children the dental age is later than in chronological age and based on chronological age, there was no difference in dental age in Down Syndrome as well as normal children. In spite dental age in Down Syndrome children is descreiptively later than in normal children.

\section{Acknowledgement}

The author thanks to all of syndrome down subject, and parents for their participation and cooperation during data collection. The study was conducted under Academic Leadership Grant from Padjadjaran University.

\section{Author's Contributions}

All authors equally contributed in this work.

\section{Ethics}

The author report no conflict of interest.

\section{References}

Agurto, G.H., T. Satake, T. Maeda and Y. Akimoto, 2009. Dental age in Japanese children; A modified Demirjian method. Ped Dent. J., 19: 82-8. DOI: 10.1016/S0917-2394(09)70157-0

Apriyono, D.K., 2016. Metode penentuan usia melalui gigi dalam proses identifikasi korban. CDK J.

Cohen, M.M., 1982. Pediatric Dentistry. 2nd Edn., Mosby Co., Philadelphia.

Diz, P., J. Limeres, A.F.P. Salgado, I. Tomas and L.F. Delgado et al., 2011. Correlation between dental maturation and chronological age in patient with cerebral palsy, mental retardation and Down syndrome. Res. Devel. Disabilities. Elsevier, 32: 808-17. DOI: 10.1016/j.ridd.2010.10.019

Finn, S.B., 2005. Clinical Pedodontics. 3rd Edn., WB Saunders Co, Philadelphia.

Ghosh, S., E. Feingold and S.K. Dey, 2010. Etiology of down syndrome: Evidence for consistent association among altered meiotic recombination, nondisjunction and maternal age across populations. J. Med. Genet A, 7: 1415-20.

Grupta, S., 1996. Assessment of puberty growth spurt in boys and girls: A dental radiographic method. J. Ind. Society Pedodontics Preventive Dentistry, 14: 4-9.

Hidajat, S., H. Garna, P.S. Idjradinata and A. Surjono, 2005. Pemeriksaan dermatoglifik dan penilaian fenotip sindrom down sebagai uji diagnostik kariotip aberasi penuh trisomi 21. Sari Pediatr, 7: 97-104.

Hurairah, K., 2012. Prevalensi kejadian penyakit jantung kongenital pada anak penderita sindrom down di RSUP haji adam malik pada tahun 2008-2010. Medan Univesitas Sumatera Utara.

Maber, M., H. Liversidge and M. Hector, 2009. Accuracy of age estimation of Radiographic methods using developing teeth. Forensic Sci. Int., 159: 68-73. DOI: 10.1016/j.forsciint.2006.02.019

McDonald, R.E. and D.R. Avery, 2000. Dentistry for the Child and Adolescent. 2nd Edn., The CV Mosby Company, St Louis.

Moraes, M.E., L.C. Moraes, G.N. Dotto, P.P. Dotto and L.R. dos Santos, 2007a. Dental anomalies in patients with down syndrome. Braz. Dent. J., 18: 346-350. DOI: 10.1590/S0103-64402007000400014 
Moraes, M.E., M.S. Bastos, L.R. Santor, J.C. Moraes and L.C. Moraes et al., 2007b. Dental age in patients with down Syndrome. Braz Oral. Res., 21: 259-64. DOI: $10.1590 / \mathrm{S} 1806-83242007000300012$

Moyers, R.E., 2001. Handbook of Orthodontics. 4th Edn., Year Book Medical Publishers Inc., Chicago.

Mussig, D., R. Hicklel and S. Zschiesche, 2011. The eruption of deciduous teeth in children with various forms of Down's Syndrome and congenital heart defects. Res. Devel. Disabilities. Elsevier, 32: 808-17.

Ondarza, A., L. Jara, P. Munoz and R. Blanco, 2011. Sequence of eruption of deciduous dentition in a children sample with Down's syndrome. Res. Devel. Disabilites Elsevier, 32: 808-17.

Rinaya, D., 2003. Faktor-faktor yang harus diperhatikan pada penatalaksanaan pasien Down Syndrome dalam perawatan Endodonti. Medan: Universitas Sumatera Utara.

Sjarif, W., 2011. Kiat sukses menangani pasien handicapped dalam Praktek Dokter Gigi. Prosiding Bandung Dentistry, 8: 249-60.
Smith, H., 1991. Standard of human tooth formation and dental age assessment. Adv. Dent. Anthropology.

Stewart, R.E., 1982. Pediatric Dentistry: Scientifi Foundations and Clinical Practice. 1st Edn., Mosby, St. Louis, ISBN-10: 0801648041, pp: 1027

Suryo, 1986. Genetika Manusia. 1st Edn., Gajah Mada University Press, Yogyakarta, ISBN-10: 9794200220, pp: 540.

Tanner, J.M., 1975. Assessment of Skeletal Maturity and Prediction of Adult Height: TW2 Method. 1st Edn., Academic Press, London.

Toscano, M., 2007. Estagios cronologicus de desenvolvimento dentario em criancas portadoras de sindrome de Down. In: Dental age in patient with Down Syndrome. Braz. Oral. Res., 21: 259-64. 